\title{
ВИКОРИСТАННЯ МОЛОДДЮ СОЦАЛЬНОГО КАПІТАЛУ В ПРОЦЕСІ СТАНОВЛЕННЯ ПОЛІТИЧНОЇ КУЛЬТУРИ
}

\begin{abstract}
Описано структурно-функціональні особливості використання молоддю соціального капіталу в ході становлення їі політичної культури. Визначено, що соціальний капітал як психологічний ресурс - це соціально-психологічні можливості соціального мікросередовища, використовуючи які особистість може досягати власних цілей, а також сприяти реалізації цілей групи, до якої вона належить. Зазначено, що політична культура - це система психологічних настановлень, які формують взаємодію особистості з політичним середовищем; певний рівень усвідомлення політичних процесів, довіри до соціальнополітичних інститутів, поділяння цінностей свободи, толерантності, спроможності особистості активно долучатися до суспільнополітичних процесів. Виділено компоненти політичної культури (уявлення особистості про політику, політичні цінності особистості, політичні символи особистості, мотиви участі особистості в політичному житті, політична поведінка особистості) та компоненти соціального капіталу (ефективність соціальної взаємодії, соціальна згуртованість, соціальна ідентифікація, міжособова довіра, готовність до взаємодопомоги). Описано процес становлення політичної культури на основі соціального капіталу як психологічного ресурсу, в якому: ефективність соціальної взаємодії, що базується на навичках спілкування особи, іiі відчуженості від соціуму, впливає на становлення всіх компонентів політичної культури молодої особи і виконує функцію політичної комунікації; соціальна ідентифікація відображає роль відчуття належності до групи під час формування толерантності, яка $є$ політичною цінністю, уявлень про політику і мотивів до участі в політиці, виконує функцію соціалізації та рекрутингу; соціальна згуртованість, базуючись на процесі гуртування та горизонтальних взаємодіях у соціумі, діє на всі компоненти політичної культури, виконує функцію формування інтересів; міжособова довіра формує мотиви політичної участі, виконує функцію накопичення інтересів.

Ключові слова: соціальний капітал, політична культура, структурний функціоналізм, дисперсійний аналіз, психологічний ресурс.
\end{abstract}

Проблема. Сучасна політична культура - це складна система політичних уявлень, цінностей, залученості та виявів активності в політичному середовищі. Як зазначає Г. Алмонд, набір політичних культур усіх разом узятих членів суспільства формує його загальну політичну культуру. Остання буває трьох типів: парафіяльною, підданською, активістською [1]. Таке формування неможливе без тісної соціальної взаємодії в суспільстві: мережі соціальних контактів, довіри серед членів спільноти, наявності спільних життєвих поглядів [2]. 
Обидва концепти, політична культура і соціальний капітал, дістали наразі досить глибоке наукове обгрунтування в політологічній та соціологічній науках відповідно. Але явища і процеси, які утворюють соціальний капітал (формування і використання мереж комунікації, довіра в спільноті тощо), зазнають впливу багатьох, у першу чергу психологічних, чинників, які $є$ певним психологічним ресурсом. Політичну ж культуру більшою мірою розглядають як спільногрупове надбання, через що неправомірно залишаються поза увагою психологічні характеристики, які впливають на формування політичної культури окремо взятої особистості. Адже, за Алмондом, політична культура спільноти - це набір приватних політичних культур людей, які ії складають. А отже, йдеться про дослідження в межах психологічного дискурсу впливу соціального капіталу як психологічного ресурсу становлення політичної культури.

Meта cmammi: виявити основні напрямки використання молоддю соціального капіталу в процесі становлення її політичної культури.

Концепція соціального капіталу належить до кола зацікавленості таких відомих дослідників, як Дж. Коулман, Р. Патнем, Ф. Фукуяма та ін. [2-5]. На сьогоднішній день можна також говорити і про значну кількість публікацій вітчизняних науковців у сфері вивчення соціального капіталу [6; 7].

Першим соціальним психологом, хто безпосередньо звернувся до аналізу соціального капіталу, був П. М. Шихірев. Він дослідив, які чинники впливають на самостійне нарощування соціального капіталу, і висловив гіпотезу про те, що останній народжується з поєднання якихось особливих, якісних стосунків між людьми з їхньою життєдіяльністю [8]. Соціальний капітал у сучасних психологічних дослідженнях трактується як сукупність актуальних або потенційних ресурсів, що пов'язані з наявністю міцних зв'язків, інституціоналізованих відносинами взаємного знайомства і визнання [9]. При цьому психологічний ресурс людини - це стан, у якому в неї найбільше свободи та максимальна кількість виборів. Ресурсом $\epsilon$ все, що може привести людину до відчуття щастя, сили, впевненості, необхідних для розв'язання якихось iii проблем. Ресурс - це також стратегії досвіду, за допомогою яких можна перейти від актуального стану до бажаного результату. Така ресурсозабезпеченість проявляється і в соціальному мікросередовищі, що знаходить відображення в характері та інтенсивності змін [10].

Узагальнюючи ці твердження, ми характеризуємо поняття соиіального капіталу як психологічного ресурсу так: це сочіальнопсихологічні можливості соиіального мікросередовища, використовуючи які особистість може досягати власних иџілей, а також сприяти реалізації цүілей групи, до якої вона належить. 
Іншим базовим твердженням у нашому дослідженні $є$ поняття політичної культури.

Одне $з$ перших трактувань поняття “політична культура" запропонував свого часу I. Г. Гердер, який цим терміном позначав рівень зрілості культури [11]. В українській політичній науці В. К. Липинський ще на початку XX ст. поняття політичної культури визначав як певний рівень бажання та вміння верств населення використовувати в політичній активності свої знання про політику та попередній досвід громадської діяльності [12]. Сучасна українська психологічна наука розглядає такі суміжні 3 політичною культурою категорії, як політична компетентність, ціннісні моделі політичної взаємодії, громадські ставлення [13], психологічна готовність до політичної участі, мотивація до політичної участі, моделі прийняття політичного рішення, громадянська відповідальність [6].

Сьогодні політичну культуру систематично вивчають, зокрема, Г. Алмонд і С. Верба. Дослідники запропонували таке іiі тлумачення: це система суспільства, яка об'єднує знання про політичне середовище, почуття щуодо нього й оцінку иьього середовища його членами. Поняття політичної культури усуває розрив між вивченням особи і політичної системи в цілому. За версією вчених, політична культура охоплює політичні спрямування трьох типів, а тому буває патріархальною, підданською або ж передбачає активну участь. Названі спрямування $є$ джерелом для трьох типів політичної культури: патріархальної, підданської й культури участі. Однак ідеальні типи політичного спрямування в чистому вигляді на практиці, зрозуміло, не трапляються вони співіснують і не заперечують один одного [1].

Г. Екстейн вважає, що політична культура співіснує з більш загальною культурою i, найімовірніше, грунтується на ній. При цьому в ній можна виділити дві найбільш важливі складові: перша - це високий рівень соціальної довіри і відповідальність, друга - те, що можна назвати “громадянськістю”, під якою дослідник розуміє специфічну тенденцію: учасники соціального процесу намагатимуться діяти більше спільними зусиллями багатьох рівних учасників, ніж за зразком вертикальних ієрархічних взаємин. Звідси випливає, що політична культура передбачає масове визнання суспільством демократичних політичних цінностей, а також впровадження в політичне життя діяльності різноманітних політичних структур, принципів політичного плюралізму й толерантності [14].

Отже, політичну культуру можна розглядати як по горизонталі (наявність певних типів політичної культури в суспільстві), так і по вертикалі, коли досліджується рівень вияву певного типу політичної культури. У цьому дослідженні ми зосередили увагу на вивченні рівня вияву психологічних рис, які безпосередньо впливають на становлення 
політичної культури. Останню ми трактуємо як певний рівень усвідомлення індивідом політичних прочесів, довіри до соціально-політичних інститутів, поділяння иінностей свободи, толерантності, спроможності особистості активно долучатися до суспільно-політичних проuеcis.

На основі вищевикладеного можна зробити висновок, що політична культура і соціальний капітал - розгалужені психологічні системи, у кожній з яких поєднуються окремі структурні компоненти, які в ході взаємодії утворюють вектори взаємовпливів. Отже, потрібен такий категоріальний апарат, який би дав змогу описати складну структуру впливу соціального капіталу як психологічного ресурсу на політичну культуру молоді.

Цілком придатним для вирішення цього завдання $\epsilon$, на нашу думку, структурний функціоналізм. Він дає змогу прояснити специфічну роль кожного структурного компонента соціального капіталу в становленні політичної культури. Адже, як стверджує С. Уосбі, структурнофункціональний аналіз визначає важливі структури і потім намагається простежити їх функції [15].

Структурний функціоналізм уперше було використано в антропології, а згодом вдосконалено як спосіб соціологічного аналізу. Підгрунтям для нього стали ідеї Е. Дюркгайма, який проаналізував основну структуру суспільства, його різні частини, соціальні системи. Суспільство, на думку Дюркгайма, слід розглядати як єдине ціле. Його утворюють певні складові, і всі вони щільно пов'язані між собою. Ці складові виконують покладені на них обов'язки, але не $\epsilon$ повністю незалежними одна від одної. Дослідник також зазначав, що як система в цілому здійснює певні функції, так і ії складові можуть виконувати свої специфічні ролі [16].

Основними поняттями теорії структурного функціоналізму Р. Мертона є “функція” і “дисфункція”. Функції, за Мертоном, - це спостережувані результати роботи саморегуляції системи або пристосування іiі до середовища. Дисфункції - це спостережувані результати діяльності, які послаблюють саморегуляцію даної системи або ï пристосування до середовища [17].

У політичному дискурсі структурним функціоналізмом для створення власних моделей політичної системи послуговувалися Г. Алмонд і Д. Істон. Працюючи над створенням функціональної теорії державного устрою, вони розділили функції політичної системи на дві великі категорії - вхідні і вихідні. Ці терміни було запозичено з економіки для аналізу функцій політичних систем і їх структур. Таким чином, дослідники виокремили такі вхідні функції: а) політична соціалізація і рекрутинг, б) артикуляція інтересу, в) накопичення інтеpecy, г) політична комунікація. До вихідних функцій належать: 
а) створення правил, б) використання правил, в) обговорення правил. Як зазначають Алмонд та Істон, вхідні функції, як правило, здійснюються за допомогою недержавних організацій та установ, до яких належать групи тиску, групи інтересів, партії, навчальні заклади. Уряд не має можливості істотно впливати на ці функції $[1 ; 6]$.

На попередніх етапах нашого дослідження було обгрунтовано та сформовано батарею методик для дослідження компонентів соціального капіталу як психологічного ресурсу й політичної культури. Було виділено такі чинники становлення соціального капіталу як психологічного ресурсу: 1) соціально-інституційне пізнання (відображає бажання молоді підвищити свій соціальний статус без серйозних зусиль, лише імітуючи діяльність еліт); 2) модуль близької соціальної контактності (оцінює активність та експресивність комунікації серед молоді); 3) рівень відчуженості (впливає на контакт із соціальною групою та включеність у іiі існування); 4) етнічна безпека - самоповага (розділяє поняття етнічної ідентичності як один із чинників безпеки в колективі і поняття самоповаги як один із чинників власного життєтворення); 5) модуль поведінки (свідчить про залежність становлення психологічної ресурсності соціального капіталу від обраної моделі поведінки); 6) професійні можливості (відображає бажання молодої особи використовувати для власного професійного зростання соціальні контакти в певних соціальних колах); 7) проведення дозвілля (описує вузьке коло спілкування молоді, що може ії емоційно підтримати); 8) етнонаціональна недовіра (говорить про те, що важливість національності для особистості породжує модель поведінки, заснованої на скептицизмі та недовірі) [17].

Особливості прояву політичної культури молодої особи можна об'єднати в три групи: 1) компетентність особистості в політиці (уявлення про політику, політична суб'єктність, усвідомлення себе як громадянина); 2) статус залученості до політичного середовища (статус політичної залученості, мотиви громадянської активності, мотивація взаємодії із соціальними інститутами), 3) громадська активність (мобілізаційна політична активність, терпимість у громадській діяльності, взаємодія із владою).

Для більш детального дослідження впливу соціального капіталу як психологічного ресурсу на становлення політичної культури ми взяли за основу вищеназвані чинники і визначили шкали, які найбільш точно відображають вияви елементів досліджуваних явищ. Статистичним методом, який використовувався для аналізу результатів дослідження, був дисперсійний аналіз. Рівень становлення того чи того компонента політичної культури ми відстежували за допомогою таких шкал: 
- уявлення особистості про політику - шкала "уявлення про демократію" анкети "Громадянство II";

- політичні цінності особистості - “індивідуалізм” модуля дослідження цінностей Г. Гофстеде, шкали “толерантність” і “довіра до соціально-політичних інститутів" анкети "Громадянство II";

- політичні символи особистості - шкали "схильність виправдовувати авторитаризм" методики політичних настановлень Г. Бієрбраура і “культурна ідентифікація” методики дослідження основних тенденцій політичної ідентичності;

- мотиви участі особистості в політичному житті - шкали “життєзабезпечення” методики діагностики мотиваційної структури особистості В. Е. Мільмана і “владне самоствердження” опитувальника механізмів політико-ідеологічного самовизначення (ОМПІС) Г. В. Циганенко;

- політична поведінка особистості - шкала “настановлення на політичну активність" методики політичних настановлень Г. Бієрбраура.

Рівень вияву компонентів соціального капіталу як психологічного ресурсу ми відстежували за допомогою таких шкал:

- ефективність соціальної взаємодії - шкали: “легкість у спілкуванні”, “соціальна активність”, “відчуженість” методики дослідження саморегуляції та успішності міжособового спілкування (автор В. М. Куніцина);

- соціальна згуртованість - шкала "горизонтальний індивідуалізм” методики дослідження індивідуалізму-колективізму В. І. Чиркова;

- соціальна ідентифікація - шкали “відчуття належності до етногрупи” методики О. Л. Романової і “ресурс соціальних інститутів" методики KPIKS P. Стили в адаптації I. І. Семків;

- міжособова довіра - шкала “довіра до близького оточення" анкети О. М. Татарка і Н. М. Лебедєвої;

- готовність до взаємодопомоги - шкала “співробітноконвенційний” методики діагностики міжособових стосунків Л. М. Собчик (модифікований варіант інтерперсональної діагностики індивідуальних стилів міжособової поведінки Т. Лірі).

Попередньо було проведено очищення незалежної змінної (компоненти соціального капіталу) за допомогою контролю регресії до середнього.

Ми поставили собі за мету створити структурно-функціональну модель становлення політичної культури молоді, яка б відображала структуру формування політичної культури на основі соціального капіталу як психологічного ресурсу та його функцій. У межах цього процесу структурними компонентами можна вважати точки взаємодії 
соціального капіталу як психологічного ресурсу і політичної культури. T. Парсонс структурні компоненти в системі розглядає як незалежні змінні, а отже, вплив кожного з них пропонує вивчати як рівнозначні елементи [3]. Тому елементи різнитимуться лише характером та інтенсивністю впливу на становлення політичної культури молодої особи.

Найбільш помітний вплив на становлення політичної культури молоді справляє елемент соціального капіталу “ефективність соціальної взаємодії”. Він досліджувався за шкалою “легкість у спілкуванні”, що показала значущий результат впливу, як і шкали "толерантність" $(\mathrm{F}=5,149 ; \mathrm{p}=0,007)$ та "довіра до соціально-політичних інститутів" $(\mathrm{F}=8,225 ; \mathrm{p}=0,000)$, які відображають вияв компонента "політичні цінності особистості”. Значущий зв'язок простежується також зі шкалою “уявлення про демократію” (F=3,149; $\mathrm{p}=0,035)$, яка відображає вияв показника "уявлення особистості про політику". Вплив шкали “соціальна активність” зафіксовано лише щодо шкали “довіра до соціально-політичних інститутів" ( $\mathrm{F}=5,431 ; \mathrm{p}=0,005)$, що корелюе 3 показником “політичні цінності особистості". Наступною шкалою, яка відображає вияв показника соціального капіталу "ефективність соціальної взаємодіi”, $є$ шкала “відчуженість”. Вона показала значущий вплив на шкали, які досліджують вияви компонентів політичної культури: політичні цінності - шкала “довіра до соціально-політичних інститутів” ( $\mathrm{F}=9,05 ; \mathrm{p}=0,003)$, уявлення особистості про політику шкала “уявлення про демократію" ( $\mathrm{F}=8,049 ; \mathrm{p}=0,005)$, мотиви участі особистості в політиці - шкала “життєзабезпечення" (F=5,166; $\mathrm{p}=0,024)$, політична поведінка - шкала “настановлення на політичну активність" ( $\mathrm{F}=4,211 ; \mathrm{p}=0,041)$.

Отже, ефективна соціальна взаємодія як психологічний ресурс становлення компонентів політичної культури молодої особи постає як можливість зміни всіх компонентів політичної культури, істотно впливаючи насамперед на політичні цінності особистості та ії уявлення про політику.

Ще один компонент соціального капіталу - "соціальна ідентифікація" - досліджувався за шкалами "відчуття належності до етногрупи” питальника О. Л. Романової і “ресурс соціальних інститутів" методики KPIKS P. Стили в адаптації I. I. Семків.

За результатами однофакторного дисперсійного аналізу шкала “відчуття належності до етногрупи” пов'язана 3 трьома шкалами, які відображають три показники політичної культури: компонент “політичні цінності особистості”, який досліджувався за шкалою “толерантність" анкети "Громадянство II" $(\mathrm{F}=4,297 ; \mathrm{p}=0,015)$; компонент "уявлення про політику" - досліджувався за шкалою "уявлення про демократію" анкети "Громадянство II" ( $F=4,678 ; \mathrm{p}=0,01)$ і компонент “мотиви участі в політичній взаємодії” - досліджувався за шка- 
лою “життєзабезпечення” ( $\mathrm{F}=6,152 ; \mathrm{p}=0,003)$ методики діагностики мотиваційної структури особистості В. Е. Мільмана. Шкала "ресурс соціальних інститутів" не показала значущих взаємодій зі шкалами, які досліджують рівень вияву компонентів політичної культури.

Отже, соціальну ідентифікацію, що є психологічним ресурсом становлення політичної культури молодої особи, можна розглядати як вплив усвідомлення єдності з групою на мотиви участі особистості в політичній взаємодії, а також на її уявлення про політику. Меншою мірою він виявляється як вплив на політичні цінності.

Найбільш яскравий і глибинний вплив показника соціального капіталу як психологічного ресурсу на політичну культуру відображає компонент “соціальна згуртованість”. Він вимірювався шкалою “горизонтальний індивідуалізм” В. І. Чиркова, яка досліджує можливості особистості взаємодіяти по горизонталі і якою мірою вона орієнтується на власні сили, а якою - на колективні. Найбільш помітно цей компонент соціального капіталу впливає на політичні цінності - шкалу “довіра до соціально-політичних інститутів" ( $\mathrm{F}=4,812$ при $\mathrm{p}=0,009)$ й шкалу “індивідуалізм" (F=3,065; $\mathrm{p}=0,049)$. Проте найбільш значущим та глибинним $\epsilon$ вплив соціальної згуртованості на уявлення особистості про політику (шкала “уявлення про демократію") ( $\mathrm{F}=7,782$; $\mathrm{p}=0,001)$. Соціальна згуртованість також впливає на мотиви участі особистості в політичній взаємодії (шкала “життєзабезпечення") $(\mathrm{F}=5,353 ; \mathrm{p}=0,005)$. Найменш потужним, проте значущим $\epsilon$ вплив соціальної згуртованості на політичну поведінку (шкала “настановлення на політичну активність") ( $\mathrm{F}=3,94 ; \mathrm{p}=0,021)$.

Отже, соціальна згуртованість як психологічний ресурс становлення політичної культури молодої особи постає як інструмент формування уявлень особистості про політику на основі більш активного долучення до групових процесів, більш глибокого усвідомлення себе як частини колективу завдяки горизонтальним взаємодіям у межах спільноти. Таким чином особистість може отримати нові уявлення про політичне середовище й утворити нові або коригувати вже наявні політичні ціннісні орієнтації.

Ще одним компонентом соціального капіталу, який може стати психологічним ресурсом у становленні політичної культури, є “міжособова довіра". Вона досліджувалася за допомогою шкали “довіра до близького оточення" анкети О. М. Татарка і Н. М. Лебедєвої. Значущий результат зафіксовано лише щодо мотивів участі особистості в політичній взаємодії (шкала “життєзабезпечення": $\mathrm{F}=8,074$; $\mathrm{p}=0,000)$. У процесі зростання довіри до свого близького оточення в молодої особи все чіткішим стає бачення власного місця в суспільстві загалом і у своїй соціальній групі зокрема. У неї формується впевненість у майбутньому, набувають конкретики вимоги й інтереси щодо 
політичного середовища як джерела формування та провадження легітимної влади в соціумі. 3 огляду на рівень розвитку попередніх компонентів, які відповідають за пошук нових учасників соціальної групи, їх поділ на “свій - чужий”, міжособову довіру як психологічний ресурс становлення політичної культури молоді можна розглядати як спроможність особи сформувати чіткі мотиви до участі в політичному житті суспільства.

Отже, особливості становлення політичної культури молоді на основі соціального капіталу як психологічного ресурсу виявляються у визнанні особистістю певних політичних ідей, у створенні і накопиченні нею інтересів у політичному середовищі та в ролі комунікації у цьому процесі. Ефективність соціальної взаємодії, соціальна ідентифікація, соціальна згуртованість, міжособова довіра стають структурними компонентами соціального капіталу. Їх можна розглядати як незалежні змінні: кожна структурна одиниця здатна виявляти свій вплив у будь-який момент часу політичної діяльності особистості.

Саме таку взаємодію відображає структурний компонент, який асоціюється з ефективною соціальною взаємодією і виконує функцію політичної комунікації. Остання стає сполучним елементом, який об'єднує діяльність осіб у політичному процесі, сприяє передаванню та засвоєнню нових цінностей і політичних уявлень. 3 огляду на зміст цього компонента можна виснувати, що ефективна соціальна взаємодія змінює в першу чергу політичні цінності та уявлення особистості про політичний процес. Також важливість соціального контакту простежується і в становленні мотивів участі в політичній взаємодії та самій політичній поведінці, хоча вплив на ці компоненти $є$ меншим, аніж на вищезгадані. Отже, цей структурний компонент виконує функцію політичної комунікації, яка простежується на всіх етапах становлення політичної культури.

Структурний компонент, пов'язаний із сочіальною ідентифікацією, відображає вплив на компоненти політичної культури через можливості ідентифікації та відбору особистістю нових політичних образів та уявлень про політичну взаємодію. 3 огляду на зміст цього структурного компонента можна сказати, що особистість ідентифікує насамперед мотиви до участі в політичній взаємодії, що, на нашу думку, свідчить про пошук певних вигод від участі в політичному житті. Далі формуються нові уявлення про політичне середовище. Цей структурний компонент виконує таким чином функцію соціалізації та рекрутингу, адже формує певну ідентичність особистості в політичному середовищі та створює іï образ у політиці, який передається іншим учасникам політичного процесу та поділяється ними.

Наступним структурним компонентом становлення політичної культури є соціальна згуртованість, яка показує можливості згуртова- 
ної соціальної групи створювати та поширювати нові уявлення про політичне середовище. Не менш важливим складником цього компонента є політичні цінності, які поділяє особистість. Слід зазначити, що згуртованість накладає відбиток на всі компоненти політичної культури. Можна сказати, що цей компонент відображає агрегацію в першу чергу уявлень про політичне середовище і таким чином створює певні спільні інтереси тієї чи тієї соціальної групи. Отже, структурний компонент, який уособлює соціальна згуртованість, виконує функцію агрегації інтересу: гуртування сприяє поширенню в соціальній групі уявлень про політику, формуванню та накопиченню нових політичних цінностей.

Не менш важливий структурно-функціональний компонент міжособова довіра. Він відображає накопичення інтересів, які були створені в межах попереднього компонента. Це відбувається на основі міжособової довіри в межах групи, де таким чином поширюються мотиви до участі в політичній взаємодії. Загалом цей структурний компонент виконує функцію накопичення інтересу: довіра в соціальній групі сприяє створенню ситуації захищеності та дає змогу чітко сформувати власні потреби в політичному середовищі.

Заслуговують на увагу особливості становлення політичної культури під впливом компонентів соціального капіталу на низькому, середньому та високому рівнях їх вияву.

Так, на низькому рівні свого вияву компоненти соціального капіталу характеризуються високим рівнем відчуженості, важкістю в спілкуванні з іншими, слабкою соціальною активністю, низьким рівнем ідентифікації зі спільнотою, до якої особа належить, високим рівнем індивідуалізму та низькою довірою до близького оточення. Такий тип соціального капіталу формує низький рівень політичної культури, що характеризується поверховими знаннями про політичне життя, низькою обізнаністю щодо політичного середовища, спрощеними політичними цінностями та низькою політичною активністю. Практично всі вищеописані впливи між компонентами соціального капіталу та політичної культури пов'язані прямопропорційним зв'язком: низький рівень компонентів соціального капіталу веде до формування низьких показників компонентів політичної культури. Виняток становить компонент “політичні цінності": низький рівень соціального капіталу відповідає сильно вираженому індивідуалізмові обстежуваних i середньому й вищому від середнього рівню показників за такими шкалами, як “толерантність” та “довіра до соціально-політичних інститутів і груп". Виходить, що низький рівень соціального капіталу в молодих осіб зумовлює низький рівень їхньої політичної культури, яка характеризується поверховими уявленнями про політику, браком мо- 
тивів до політичної участі, а також високим рівнем індивідуалізму, недостатньою довірою до соціально-політичних інститутів та груп.

Середній рівень соціального капіталу впливає на становлення політичної культури так само: чітко простежується лінійний взаємозв'язок між компонентами соціального капіталу і політичною культурою. Проте така дія на політичні цінності має дещо іншу природу: ефективна соціальна взаємодія демонструє позитивний вплив на рівень довіри до соціально-політичних інститутів та груп і разом із соціальною ідентифікацією - на рівень толерантності, які виконують функцію маркерів політичних цінностей молодої особистості. Водночас соціальна згуртованість негативно впливає на таку політичну цінність, як індивідуалізм. Отже, підвищення рівня соціального капіталу з низького до середнього буде супроводжуватися зростанням показників усіх компонентів політичної культури молоді, разом з тим індивідуалізм як особистісна цінність втрачатиме для неї свою значущість. Разом з тим зауважимо, що зростання показників політичних цінностей особистості в цьому процесі не відбуватиметься строго прямолінійно. Зниження ж у молодої людини рівня індивідуалізму як цінності може говорити про те, що по мірі розширення мережі спілкування, підвищення згуртованості спільноти та віднаходження все більшої кількості спільних маркерів, на основі яких відбувається ідентифікація з групою, потреба в такому високому рівні індивідуалізму знижується. Адже особа може більше довіряти членам соціальної спільноти, делегувати їм певні види роботи та отримувати від них більше допомоги.

Високий рівень соціального капіталу тягне за собою зростання показників усіх компонентів політичної культури, окрім політичних цінностей, які вирізняються специфічною природою взаємодії. Ефективність соціальної взаємодії на високому рівні свого становлення знижуватиме рівень толерантності та довіри до соціально-політичних інститутів і груп, таким же чином буде впливати соціальна ідентифікація на цінність толерантності. Проте соціальна згуртованість, порівняно із середнім рівнем соціального капіталу, на високому рівні буде спричинювати трохи вищий рівень акцентуації цінності індивідуалізму. Це підтверджує наше припущення, що в більшості випадків взаємодії 3 підвищенням рівня соціального капіталу зростає і рівень політичної культури.

Висновки. Соціальний капітал як психологічний ресурс можна розглядати як соціально-психологічні можливості соціального мікросередовища, використовуючи які особистість здатна досягати власних цілей, а також сприяти досягненню цілей групи, до якої вона належить. Політична культура - це певний рівень усвідомлення політичних процесів, довіри до соціально-політичних інститутів, поділяння цінностей 
свободи, толерантності, спроможності особистості активно долучатися до суспільно-політичних процесів.

Особливості становлення політичної культури на основі соціального капіталу як психологічного ресурсу можна описати чотирма структурно-функціональними компонентами:

- ефективність соціальної взаємодії - базується на навичках спілкування особи, доланні нею своєї відчуженості від соціуму; впливає на становлення всіх компонентів політичної культури молодої особи і виконує функцію політичної комунікації;

- соціальна ідентифікація - виявляється у відчутті належності до групи під час формування толерантності як політичної цінності, уявлень про політику і мотивів до участі в ній; виконує функцію соціалізації та рекрутингу;

- соціальна згуртованість - грунтується на процесах єднання та взаємодії в соціальному середовищі по горизонталі; впливає на всі компоненти політичної культури, виконує функцію формування інтересів;

- міжособова довіра - формує мотиви політичної участі, виконує функцію накопичення інтересів.

Перспективами дальшої роботи є дослідження зміни рівня вияву структурних компонентів політичної культури за умови активізації психологічного ресурсу соціального капіталу.

\section{Лimepamypa}

1. Almond G. Comparative political systems / G. Almond // The Journal of Politics. - 1956. - Vol. 18. - № 3. - P. 391-409.

2. Коулман Дж. Капитал социальный и человеческий / Дж. Коулман // Общественные науки и современность. - 2001. - № 3. - С. 122 - 139.

3. Parsons T. The Concept of Society: The Components and Their Interrelations / T. Parsons // Evolutionary and Comparative Perspectives. - Englewood Cliffs (New Jersey) : Prentice-Hall, 1966. - P. 5-29.

4. Фукуяма Ф. Доверие: Социальные добродетели и путь к процветанию / Фрэнсис Фукуяма. - М. : АСТ, 2004. - 730 с.

5. Putnam R. Making Democracy Work: Civic Traditions in Modern Italy / R. Putnam - Princeton, New Jercey: Princeton University Press, 1993. - 258 p.

6. Формування навичок ефективної політичної участі молоді : технології психологічного супроводу : монографія / за наук. ред. Л. О. Кияшко ; Нац. акад. пед. наук України, Ін-т соц. та політ. психології. - К. : Міленіум, 2014. $-314 \mathrm{c}$.

7. Easton D. A System Analysis of Political Life / D. Easton. - New York : John Wiley and Sons, Inc, 1965. - $532 \mathrm{p}$.

8. Шихирев П. Н. Природа социального капитала: социальнопсихологический поход / П. Н. Шихирев // Общественные науки и современность. -2003 . - № 2. - С. 17 - 32 . 
9. Семків I. I. Соціальний капітал як чинник громадянської активності студентської молоді: психологічна модель : дис. ... канд. психол. наук : 19.00.11 / Семків Ірина Ігорівна ; Нац. ун-т ім. Івана Франка. - Львів, 2009. $-268 \mathrm{c}$.

10. Лесечко М.Д. Соціальний капітал: теорія і практика: [монографія] / М. Д. Лесечко, О. Г. Сидорчук. - Л. : ЛРІДУ НАДУ, 2010. - 220 с.

11. Гердер И. Г. Идеи к философии истории человечества / И. Г. Гердер ; пер. с нем. и прим. А. В. Михайлова. - М. : Наука, 1977. - 703 с.

12. Липинський В. К. Листи до братів-хліборобів про ідею і організацію українського монархізму [Електронний ресурс] / В'ячеслав Казимирович Липинський; Ін-т східноєвроп. дослідж. НАН України. - 1995. - Режим доступу : http://diasporiana.org.ua/wp-content/uploads/books/3615/file.pdf.

13. Соціальне научання: механізми розвитку політичних ставлень молоді : [наук.-метод. посіб.] / [І. В. Жадан, І. А. Дідук, С. І. Позняк та ін.] ; за ред. I. В. Жадан ; Нац. акад. пед. наук України, Ін-т соц. та політ. психології. Кіровоград : Імекс-ЛТД, 2012. - 352 с.

14. Eckstein H. A. A Culturalist Theory of Political Change / H. A. Eckstein // American Political Science Review. - 1988. - Vol. 82. - № 3. - P. 789 - 804.

15. Wasby S. L. Political science: the discipline and its dimensions / Stephen L. Wasby, William C. Baum. - Scribner, 1970. - 586 p.

16. Дюркгейм Э. Социология. Ее предмет, метод, предназначение / Эмиль Дюркгейм ; пер. с фр., сост., послесл. и прим. А. Б. Гофмана. - М. : Канон, 1995. - 352 с.

17. Мертон Р. Социальная теория и социальная структура / Роберт Мертон. М. : АСТ, Хранитель, 2006. - 880 с.

18. Блозва П. І. Чинники становлення соціального капіталу як психологічного ресурсу особистості / П. І. Блозва // Психологія і особистість. - 2016. № 2 (10). - C. 65-78.

\section{References}

1. Almond, G. (1956). Comparative political systems. The Journal of Politics, 18(3), 391-409.

2. Coleman, J. (2001). Kapital sotsialnyy i chelovecheskiy [Social and Human Capital]. Obshhestvennyye nauki i sovremennost [Social Sciences and Modernity], 3, 122-139 (rus).

3. Parsons, T. (1966). The Concept of Society: The Components and Their Interrelations. Evolutionary and Comparative Perspectives. Englewood Cliffs, New Jersey, Prentice-Hall.

4. Fukuyama, F. (2004). Doveriye: Sotsialnyye dobrodeteli i put $k$ protsvetaniyu [Trust: Social virtues and the path to prosperity]. Moscow: AST Publ. (rus).

5. Putnam, R. (1993). Making Democracy Work: Civic Traditions in Modern Italy. New Jercey: Princeton University Press.

6. Kyiashko, L. O. (Ed.). (2014). Formuvannia navychok efektyvnoi politychnoi uchasti molodi: tekhnolohii psykholohichnoho suprovodu [Formation of skills of youth effective political participation: technologies of psychological support]. Kyiv: Milenium Publ. (ukr). 
7. Easton, D. A. (1965). System Analysis of Political Life. New York: John Wiley and Sons, Inc.

8. Shikhirev, P. N. (2003). Priroda sotsialnogo kapitala: sotsialnopsikhologicheskiy podkhod [The nature of social capital: a social and psychological approach]. Obshchestvennyye nauki i sovremennost [Social Sciences and Modernity], 2, 17-32 (rus).

9. Semkiv, I. I. (2009). Sotsialnyi kapital yak chynnyk hromadianskoi aktyvnosti studentskoi molodi: psykholohichna model [Social capital as a factor of civic activity of students: psychological model]. Ph. D. Thesis. Lviv Ivan Franko national University Press (ukr).

10. Lesechko, M. D., and Sydorchuk, O. H. (2010). Sotsialnyi kapital: teoriia $i$ praktyka [Social Capital: Theory and Practice]. Lviv (ukr).

11. Gerder, I. G. (1977). Idei k filosofii istorii chelovechestva [Ideas to the philosophy of human history]. Moscow: Nauka Publ. (rus).

12. Lypynskyi, V. K. (1927). Lysty do brativ-khliborobiv. Pysani u 1919-1926 rr. [Letters to fellow farmers. Scriptures 1919-1926]. Viden (ukr).

13. Zhadan, I. V., Diduk, I. A., Pozniak, S. I. (2012). Sotsialne nauchannia: mekhanizmy rozvytku politychnykh stavlen molodi [Social education: mechanisms of development of youth political attitudes]. Kirovohrad: Imeks-LTD Publ. (ukr).

14. Eckstein, H. A. (1988). A Culturalist Theory of Political Change. American Political Science Review, 82 (3), 789-804.

15. Wasby, S. L. and Baum, W. C. (1970). Political science: the discipline and its dimensions. Scribner.

16. Durkheim, E. (1995). Sotsiologiya. Eye predmet, metod, prednaznacheniye [Sociology. Its subject, method, purpose]. Moscow: Kanon Publ. (rus).

17. Merton, R. (2006). Sotsialnaya teoriya i sotsialnaya struktura [Social Theory and Social Structure]. Moscow: AST, Khranitel Publ. (rus).

18. Blozva, P. (2016). Chynnyky stanovlennia sotsialnoho kapitalu yak psykholohichnoho resursu osobystosti [Factors of the formation of social capital as a personal psychological resource]. Psykholohiia $i$ osobystist [Psychology and personality], 2(10), 65-78 (ukr).

\section{Blozva P. I. Using social capital by youth in the process of political cul- ture becoming}

The structural and functional features of youth using the social capital in the process of their political culture becoming are described. It is determined that social capital as a psychological resource is the social and psychological capabilities of social micro-environment, using which personality can achieve their own goals and assist to realize group goals to which he or she belongs. It is noted that political culture is a system of psychological attitudes that form the interaction of personality with political environment; a certain level of awareness of political processes, trust in social and political institutions, the sharing of freedom values, tolerance, and the personal ability to actively engage in social and political processes. The components of political culture (perceptions about politics, political values, political symbols, individual motives to participate in political life, political behavior of personality) and components of social capital (effectiveness of social interaction, social cohesion, 
social identification, interpersonal trust, readiness for mutual assistance) are selected. The process of political culture formation on the basis of social capital as a psychological resource is described, in which the effectiveness of social interaction, which based on personal communicative skills, personal alienation from society, affects on the formation for all components of youth political culture and serves as a function of political communication; social identification reflects the role of sense of belonging to the group during the tolerance formation which is political value, ideas about politics and motives for participation in politics, serves as a function of socialization and recruiting; social cohesion based on the process of grouping and interaction in society on the horizontal level, acts on all components of political culture, serves as a function of interests creation; interpersonal trust forms the motives of political participation, serves the function of interests accumulation.

Key words: social capital, political culture, structural functionalism, dispersion analysis, psychological resource.

() Блозва П. I. 
